\title{
Substituent Effects on the Gas-Phase Pyrolyses of 2-Substituted Ethyl $N, N$-Dialkylcarbamates: A Theoretical Study
}

\author{
Chang Kon Kim, Dong Jin Kim, Hui Zhang, Yih-huang Hsieh, Bon-Su Lee, Hai Whang Lee, and Chan Kyung Kim \\ Department of Chemistry, Inha Lniversity Incheon 402-751, Korea. ${ }^{\circ}$-mail: kckunganiha.ackr \\ Recerved March 23, 2007
}

\begin{abstract}
The R- and Z-substituent effects for the gas-phase thermal decompositions of carbamates. $\mathrm{R}_{2} \mathrm{NC}(=\mathrm{O})$ $\mathrm{OCH}_{2} \mathrm{CH}_{2} \mathrm{Z}$. have been investigated theoretically at B3LYP level with $6-3 \mathrm{lG}(\mathrm{d})$ and $6-3 \mathrm{l}++\mathrm{G}(\mathrm{d}$.p) basis sets. Both the $\mathrm{Z}$ - and R-substituent effects on reactivity $\left(\Delta \mathrm{H}^{*}\right)$ were well consistent with experimental results. although the R-substituent effect was underestimated theoretically. No correlations were found between activation enthalpies and reaction enthalpies. The substituent effects on reactivity seemed to be complicated at a glance. but were understandable by concurrent electronic and steric factors. Variations of bond lengths at TS stnictures were well correlated with the Taft's $\sigma$ values and the TS structures became tighter as the $Z$ substituent became a stronger electron-acceptor $(\delta \dot{\sigma}>0)$. However the effects of R-substituents on the TS stnictures were much smaller when compared to those of Z-substituents.
\end{abstract}

Key Words : Pyrolysis of carbamates, Hybrid density functional method. Variation of TS structures, Linear free energy relationship

\section{Introduction}

Thermal decomposition of 2-(Z)-substituted $N, N$-dialkylcarbamates has been known to produce an amine. an olefin and carbon dioxide through a stepwise mechanism shown in Chart $l^{l}$ along with some important atom numbering. In a previous work - we have investigated theoretically the gasphase thermal decomposition of ethyl $N, N$-dimethylcarbamate $\left(\mathrm{R}=\mathrm{CH}_{3}\right.$ and $\mathrm{Z}=\mathrm{H}$ in $\left.\mathrm{I}\right)$ and found that the first step proceeds through a six-membered cyclic transition state (TS). II. and becomes a rate-limiting step due to entropy effects. The six-membered structures were generally accepted as genuine TS structures for thermal decompositions of acetates and carbonates. ${ }^{3}$ and hence the thermal decompositions of carbamates might be similar to those of acetates and related compounds.

In thermal decompositions of 2-(Z)-substituted ethyl acetates. $\mathrm{CH}_{3} \mathrm{CO}_{2} \mathrm{CH}_{2} \mathrm{CH}_{2} \mathrm{Z}$. various substituent effects have been used to explain the reaction mechanism. ${ }^{4}$ For example. electron-withdrawing Z-substituents showed a linear correlation with inductive parameters. $\sigma_{\text {I. }}$ with a slope $\rho_{\mathrm{I}}=-1.03$ $\left(r=0.961\right.$ at $\left.400^{\circ} \mathrm{C}\right)$, and alkyl and polar substituents separated by at least three methy lene groups were correlated with Hancock 's steric parameters. $E_{\mathrm{S}}$. ${ }^{5}$ with slope $\delta=-0.12$ $\left(r=0.916\right.$ at $\left.400^{\circ} \mathrm{C}\right)$. Recently an interesting work on Zsubstituent effects for 2-(Z)-substituted ethyl $N_{1} N$-dimethylcarbamates. $\left(\mathrm{CH}_{3}\right)_{2} \mathrm{NCO}_{2} \mathrm{CH}_{2} \mathrm{CH}_{2} \mathrm{Z}$. was reported $\mathrm{How}$ ever, for these carbamates. no good results were obtained using various linear free energy relationships. Only the application of the Taft $\sigma^{*}$ values $^{7}$ gave three straight lines at the origin of $\sigma^{*}\left(\mathrm{CH}_{2}\right)=0.0$. (i) alkyl substituents with $\rho^{*}=$ $-1.94(\mathrm{r}=0.977)$. (ii) electron-withdrawing polar substituents with $\rho^{*}=-0.12(\mathrm{r}=0.936)$. and (iii) multiplebonded substituents or electron-withdrawing substituents interposed by $\mathrm{a} \mathrm{CH}_{2}$ at the 2-position of the ethyl ester with $\rho^{*}=+0.49(\mathrm{r}=0.991)$. These results indicated that the

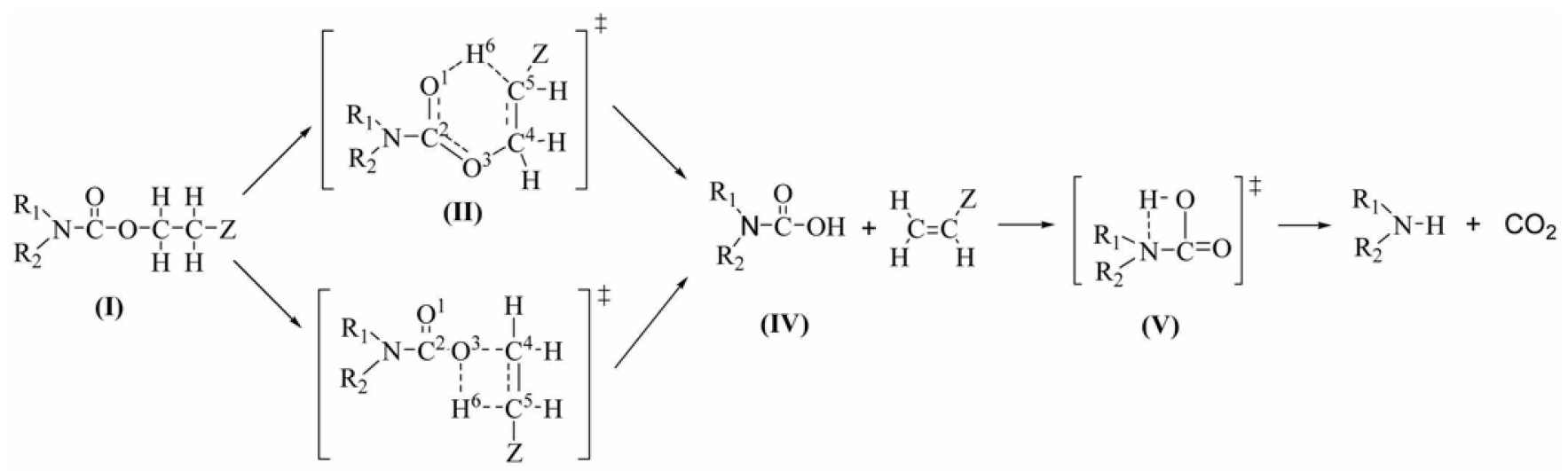


mechanistic criteria might be different although the conmon features of the TS structures seemed to be operative both in the cases of carbamates and acetates.

On the other hand. the rates of thermal decompositions were decreased as a bulky group. $R$, was substituted at the nitrogen atom of the carbamate. ${ }^{8}$ For example. the replacement of two methyl groups on the nitrogen atom by phenyl groups resulted in a rate decrease by a factor of 10 . This strongly implied that the steric factor had strong effect as suggested by experiments. However it has also been reported that the rate decreased for saturated heterocyclic carbamates but increased for unsaturated heterocyclic carbanates due to electronic factors. ${ }^{9}$ Therefore it would be interesting to analyze both factors - steric and electronic factor. for the substituent effects on the nitrogen atom of the carbamates.

In this work. the substituent effects for thermal decompositions of the carbamates shown in Chart I were studied theoretically in order to elucidate the R- and Z-substituent effects on the reaction mechanism as a continuing work in our group on the theoretical elucidation of structures and reaction mechanism. ${ }^{\text {ti }}$

\section{Calculations}

In a previous theoretical work for the thernal decomposition of ethyl $N, N$-dimethyl carbamate, ${ }^{2}$ the activation enthalpies $\left(\Delta \mathrm{H}^{\dot{x}}\right)$ calculated at B3LYP levels were consistent with the experimental values. Therefore we have studied thermal decomposition reactions by using the B3LYP level with $6-31 \mathrm{G}(\mathrm{d})$ and $6-31++\mathrm{G}(\mathrm{d}$,p) basis sets in this work. Throughout this paper, $\mathrm{B} 3 \mathrm{LYP} / 6-3 \mathrm{I}++\mathrm{G}(\mathrm{d}$.p) results were used in the discussions unless noted otherwise.

All the stationary species were fully optimized and characterized by frequency calculations with all positive frequencies for reactants, intermediates and products and with only one imaginary frequency for transition states (TS). ${ }^{11}$ The enthalpy changes $(\Delta \mathrm{H})$ at $633 \mathrm{~K}$ corresponding to the experimental temperature ${ }^{6}$ were calculated by using eq. (1). ${ }^{12}$ where $\Delta \mathrm{E}_{\mathrm{ZFE}}$ and $\Delta \mathrm{E}_{\mathrm{T}}$ are zero-point energy corrected electronic energy change at $0 \mathrm{~K}$ and thermal energy changes at $633 \mathrm{~K}$. respectively. All the calculations were performed with the Gaussian 98 program package. ${ }^{13}$

$$
\Delta \mathrm{H}=\Delta \mathrm{E}_{\mathrm{ZPE}}+\Delta \mathrm{E}_{\mathrm{T}}+\Delta(\mathrm{PV})
$$

\section{Results and Discussion}

(A) Z-substituent effects. As mentioned above. it has been experimentally reported that the substituent effects for the thermal decompositions of I with $\mathrm{R}=\mathrm{CH}_{3}$ showed three distinct types of correlations with the Taft's $\sigma^{*}$ values. Therefore three different types of Z-substituents were selected as a representative case for each type of a substituent: $-\mathrm{C}\left(\mathrm{CH}_{\hat{3}}\right)_{3}$ as an alkyl, $-\mathrm{Cl}$ as an electron-withdrawing and $-\mathrm{C} \equiv \mathrm{N}$ as a multiple bonded substituent together with standard substituents $\mathrm{CH}_{\hat{s}}$ (for Taft equation) and $\mathrm{H}$ (for Hanumett equation). The calculated activation enthalpies.
Table 1. Calculated and experimental activation enthalpies, $\Delta H^{z}$, and reaction enthalpies, $\Delta \mathrm{H}^{\prime \prime}$ for the first step through the sirmembered cyclic TS with $\mathrm{R}=\mathrm{CH}_{3}$ shown in Chart $\mathrm{l}$

\begin{tabular}{|c|c|c|c|c|c|}
\hline \multirow[b]{2}{*}{ Z } & \multirow[b]{2}{*}{$\sigma^{* a}$} & \multicolumn{3}{|c|}{$\Delta \mathrm{H}^{x b}$} & \multirow{2}{*}{ 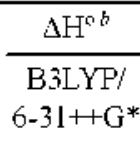 } \\
\hline & & $\begin{array}{l}\text { B3LYP/ } \\
6-31 G^{*}\end{array}$ & $\begin{array}{c}\text { B3LYP/ } \\
6-31++\mathrm{G}^{*}\end{array}$ & Exp. ${ }^{c}$ & \\
\hline$\left(\mathrm{CH}_{3}\right)_{3} \mathrm{C}$ & -0.30 & 43.1 & 39.7 & 40.5 & 7.0 \\
\hline $\mathrm{H}_{3} \mathrm{C}$ & 0.00 & 45.0 & 41.4 & 45.6 & 8.6 \\
\hline $\mathrm{H}$ & 0.49 & 44.6 & 41.0 & 43.9 & 12.6 \\
\hline $\mathrm{Cl}$ & 2.94 & 45.4 & 42.0 & 46.1 & 10.3 \\
\hline $\mathrm{N} \equiv \mathrm{C}$ & 3.64 & 38.2 & 34.9 & 36.7 & 9.1 \\
\hline
\end{tabular}

"Values are taken from Ref.' 14. "Values are in $\mathrm{kcal}^{\mathrm{mol}}{ }^{-1}$ at $633 \mathrm{~K}$. ${ }^{\mathrm{C}}$ Ref.

Table 2. The NPA of charge densities $(q)$ and changes $(\Delta q)$ on going from I to $\Pi$ in electron unit at BSLYP/6-31++G(d p) level

\begin{tabular}{|c|c|c|c|c|c|c|}
\hline \multirow{2}{*}{$Z$} & \multicolumn{2}{|c|}{1} & \multicolumn{2}{|c|}{ II } & \multirow{2}{*}{$\Delta q\left(C^{5}\right)$} & \multirow{2}{*}{$\Delta q(Z)$} \\
\hline & $\mathrm{q}\left(\mathrm{C}^{5}\right)$ & $q(Z)$ & $q^{*}\left(C^{5}\right)$ & $\mathrm{q}^{*}(\mathrm{Z})$ & & \\
\hline$\left(\mathrm{CH}_{3}\right)_{3} \mathrm{C}$ & -0.488 & -0.008 & -0.587 & 0.011 & -0.099 & 0.019 \\
\hline $\mathrm{H}_{3} \mathrm{C}$ & -0.485 & 0.014 & -0.602 & 0.031 & -0.117 & 0.017 \\
\hline $\mathrm{H}$ & -0.707 & 0.230 & -0.811 & 0.248 & -0.104 & 0.018 \\
\hline $\mathrm{Cl}$ & -0.456 & -0.093 & -0.592 & -0.075 & -0.136 & 0.018 \\
\hline$N \equiv C$ & -0.594 & -0.043 & -0.727 & -0.103 & -0.133 & -0.060 \\
\hline
\end{tabular}

$\Delta \mathrm{H}^{ \pm}$, and reaction enthalpies. $\Delta \mathrm{H}^{\circ}$, at $633 \mathrm{~K}$ for the first step through the six-membered cyclic TSs are collected in Table 1. Examination of Table I showed that the calculated $\Delta \mathrm{H}^{x}$ values at $B 3 L Y P / 6-3 I G(d)$ level were slightly larger than those at $\mathrm{B} 3 \mathrm{LYP} / 6-3 \mathrm{l}++\mathrm{G}(\mathrm{d}, \mathrm{p})$ level. However numerical differences between the calculated and experimental $\Delta \mathrm{H}^{x}$ values were as small as $0.7-4.1 \mathrm{kcal} \mathrm{mol}^{-1}$ and the relative order of activation enthalpies of both theoretical levels were fully consistent with experimental results. Therefore it could be expected that the theoretical results are sufficiently reliable. Reaction enthalpies calculated at B3LYP/6-3++G(d.p) level showed no correlation with activation enthalpies.

To examine electronic effects of $Z$-substituents. changes in atomic charge densities on going from reactant to TS. $\Delta \mathrm{q}$. were calculated by using the natural population analysis (NPA) ${ }^{14}$ and collected in Table 2. As can be seen from Table 2. the atomic charge densities revealed an interesting phenomenon. i.e. the charge density of a carbon center. $\mathrm{q}\left(\mathrm{C}^{5}\right)$, to which the $Z$-substituent is directly attached, became more negative as the reaction proceeded in all cases. These results are easily understandable - the hydrogen. which moves toward carbonyl oxy'gen. $\mathrm{O}^{1}$. seems to have proton character and hence charge density of $\mathrm{C}^{5}$ at the TS increases as depicted in Scheme 1. Thus the Z-substituent effects on the reactivity $\Delta \mathrm{H}^{x}$. in terms of pure electronic effects, were generally expected to become more favorable (unfavorable) as an electron-withdrawing (-donating) ability increases. In fact. the $\Delta \mathrm{H}^{x}$ for $\mathrm{Z}=\mathrm{CN}$ is the most favorable among reactions studied. since the electron accepting ability of $\mathrm{CN}\left(\sigma^{*}=3.64\right)$ is the largest. This is well agreed with the results of charge density analyses. 


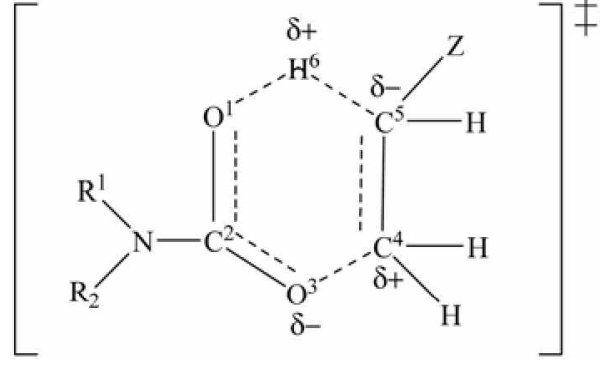

Scheme 1

However the relative order of $\Delta \mathrm{H}^{+}$for $\mathrm{Z}=\mathrm{Cl}\left(\sigma^{*}=2.94\right)$ or $\mathrm{Z}=\left(\mathrm{CH}_{3}\right)_{3} \mathrm{C}\left(\sigma^{*}=-0.30\right)$ did not follow simple relationship between Taft $s \sigma^{* 15}$ and charge density analysis. In the case of $\mathrm{Z}=\mathrm{Cl} . \sigma^{*}$ value is larger than that of $\mathrm{Z}=\mathrm{CH}_{3}\left(\sigma^{*}=0.0\right)$. which means that the activation barrier for the former should be lower than that of the latter. In fact the activation enthalpy for $\mathrm{Z}=\mathrm{Cl}$ is the highest among the systems studied in this work. This strongly suggests that $\mathrm{Cl}$ should act as a relatively stronger electron donor than $\mathrm{CH}_{3}$ contrary to general belief. In a previous work, ${ }^{16}$ we have reported the anomalous $\pi$-donating effects of $\pi$-accepting substituents in carbocationic systems and found that extent of $\pi$-donating effect is the largest for $\mathrm{Cl}$ substituent. Therefore, we believe that the lone pair orbitals on $\mathrm{Cl}$ act as a $\pi$-donor to a partially filled p-orbital on $\mathrm{C}$. In order to determine the extent of electron donation from $\mathrm{Cl}$, orbital interactions of interacting orbitals were deleted at $\mathrm{B} 3 \mathrm{LYP} / 6-3 \mathrm{I}++\mathrm{G}(\mathrm{d} . \mathrm{p})$ level by using the natural bond orbital (NBO) analy sis ${ }^{17}$ and found that the extent of $\pi$-donating effect from lone-pair orbitals of $\mathrm{Cl}$ was $0.017 \mathrm{e}$. This explains why the $\Delta \mathrm{H}^{\dot{x}}$ for $\mathrm{Cl}$ is more unfavorable than for $\mathrm{CH}_{3}$. even if the expected electronaccepting ability (based on $\sigma^{*}$ ) is larger for $\mathrm{Cl}$ than for $\mathrm{CH}_{3}$.

In the case of $\mathrm{Z}=\left(\mathrm{CH}_{3}\right)_{3} \mathrm{C}, \Delta \mathrm{q}\left(\mathrm{C}^{5}\right)$ is the most negative due to the electron donating nature of 1 -butyl group $\left(\sigma^{*}=\right.$ -0.30 ) but its activation energy is lower than that of $\mathrm{Z}=\mathrm{CH}_{3}$. Therefore. it might be expected that another effect play'ed a more important role in the cases of $Z=$ alkyl substituents. As is generally expected. steric congestion of $t$-butyyl group on going from reactant to TS could be released. since the hy bridization of $\mathrm{C}^{5}$ atom changed from $\mathrm{sp}^{3}$ to partial $\mathrm{sp}^{2}$ character as shown in Scheme 1. This implies that the steric effect is one of important factors influencing the reactivity in case of bulky substituent

(B) R-Substituent Effects. It has been experimentally reported that the reactivity for thermal decomposition of ethyl $N, N$-diethylcarbamate $\left(\mathrm{R}=\mathrm{CH}_{3} \mathrm{CH}_{3}\right)^{\text {lc }}$ was decreased slightly as compared to that of ethyl N.N-dimethylcarbanate $\left(\mathrm{R}=\mathrm{CH}_{3}\right)^{6}$ These results have been explained by the stronger electron-donating ability of $\mathrm{R}=\mathrm{CH}_{3} \mathrm{CH}_{2}$ relative to $\mathrm{R}=\mathrm{CH}_{\mathrm{s}}$. On the other hand, the reactivity was reduced when a bulky group with stronger electron-accepting ability such as a phenyl group was substituted at the nitrogen atom. ${ }^{8}$ For example. the $\Delta \mathrm{H}^{ \pm}$at $653 \mathrm{~K}$ became larger by $5.4 \mathrm{kcal}$ $\mathrm{mol}^{-1}$ when $\mathrm{R}=\mathrm{CH}_{\hat{j}}$ was replaced by $\mathrm{R}=\mathrm{Ph}$ group. Experimentally, it has been explained that the rate is decreased by the concurrent steric effect in the case with $\mathrm{R}=$ phenyl.

The theoretical results obtained in this work were well consistent with the experimental results as summarized in Table 3. The $\Delta \mathrm{H}^{ \pm}$with $\mathrm{R}=\mathrm{H}$ is favorable by $0.6 \mathrm{kcal} \mathrm{mol}^{-1}$ than that with $\mathrm{R}=\mathrm{CH}_{3}$. The $\Delta \mathrm{H}^{*}$ is larger with bulky group. $\mathrm{R}=$ phenyl or ter-butyl group. when compared with $\mathrm{R}=$ $\mathrm{CH}_{3}$.

Structurally. in $\mathrm{R}=$ tert-butyl, the dihedral angle between the carbonyl $(\mathrm{C}=\mathrm{O})$ and the $\mathrm{NR}_{\mathrm{l}}$ (or $\mathrm{NR}$ ) moiety deviated from planarity by $37.7^{\circ}$ in the reactant due to steric congestions of two bulky tert-butyl substituent. Moreover such a distortion became more severe by $5.4^{\circ}$ in the TS. Therefore the stabilizing conjugation effect between $\pi(\mathrm{C}=\mathrm{O})$ orbital and a lone pair of $\mathrm{N}$-atom is reduced. This could explain why the reactivity is reduced when tert-butyl group is substituted at the $\mathrm{N}$ atom.

However, such a dihedral angle distortion was not observed in $\mathrm{R}=$ phenyl because the deviation from planarity was less than $5^{\circ}$ for both the reactant and TS. Moreover. bond angle, $\angle \mathrm{R}_{1} \mathrm{NR}_{2}$, in reactant or TS was almost same (Table 3). This indicated that the hybridization of $\mathrm{N}$ atom is little changed on going from the reactant to TS. Instead. two phenyl rings had to rotate from the $\mathrm{NC}(=\mathrm{O})$ molecular plane in the reactant $\left(41.1^{\circ}\right.$ and $\left.68.3^{\circ}\right)$ and became $54.1^{\circ}$ and $54.6^{\circ}$ in the TS. Deviations of phenyl rings from molecular plane could be clearly resulted from the steric congestion between two bulky phenyl groups, and thus the conjugation effects of the $\mathrm{N}$ lone pair might be influenced by these changes. As a result, the reactivity $\left(\Delta \mathrm{H}^{ \pm}\right)$became less favorable for $\mathrm{R}=$ phenyl due to steric effects of bulky substituents. However, $\Delta \mathrm{H}^{ \pm}$difference between $\mathrm{R}=\mathrm{C}_{6} \mathrm{H}_{5}$ and $\mathrm{R}=\mathrm{CH}_{3}$ calculated at $633 \mathrm{~K}$ is only $0.4 \mathrm{kcal} \mathrm{mol}^{-1}$, and this is much smaller than the difference observed experimentally. Therefore. theoretical results for R-substituent effects could be underestimated. Reaction enthalpies summarized in Table 3 showed no correlation with activation enthalpies similarly to that found for Z-substituent effects.

(C) Substituent Effects on the TS Structures. In order to examine TS structure variations. some important bond lengths in TS structures were collected in Table 4. Examination of Table 4 showed that both the bond lengths of $\mathrm{d}\left(\mathrm{O}^{1}\right.$. $\left.\mathrm{H}^{5}\right)$ and $\mathrm{d}\left(\mathrm{O}^{2}-\mathrm{C}^{4}\right)$ corresponding to bond formations and bond breakings. respectively. were shortened when the electron accepting abilities of $Z$-substituents (based on the

Table 3. Calculated and experimental activation enthalpies, $\Delta \mathrm{H}^{\rightleftharpoons}$ reaction enthalpies, $\Delta H^{\circ}$, for the first step through the sixmembered cyclic TS and bond angles, $\angle \mathrm{R}_{1} \mathrm{NR}_{2}$, at the reactant, $I_{\text {, }}$ and TS, $\Pi$, for species with $Z=\mathrm{H}$ at $\mathrm{B} 3 \mathrm{LYP} / 6-3 \mathrm{I}+\mathrm{G}(\mathrm{d}, \mathrm{p})$ level

\begin{tabular}{crrrrr}
\hline \multirow{2}{*}{$\mathrm{R}$} & \multirow{2}{*}{$\sigma^{-\alpha}$} & $\Delta \mathrm{H}^{*}$ & $\Delta \mathrm{H}^{\circ 0}$ & \multicolumn{2}{c}{$\angle \mathrm{R}_{1} \mathrm{NR}_{2}$} \\
\cline { 5 - 6 } & & & & $\mathbf{I}$ & II \\
\hline $\mathrm{H}$ & 0.49 & 40.4 & 21.1 & $119.2^{\circ} \mathrm{C}$ & $119.5^{\circ} \mathrm{C}$ \\
$\mathrm{H}_{3} \mathrm{C}$ & 0.00 & 41.0 & 12.6 & $1165^{\circ} \mathrm{C}$ & $117.1^{\circ} \mathrm{C}$ \\
$\left(\mathrm{CH}_{3}\right)_{3} \mathrm{C}$ & -0.30 & 41.6 & 17.6 & $124.9^{\circ} \mathrm{C}$ & $125.1^{\circ} \mathrm{C}$ \\
$\mathrm{C}_{6} \mathrm{H}_{5}$ & 060 & 41.4 & 17.2 & $1180^{\circ} \mathrm{C}$ & $118.3^{\circ} \mathrm{C}$ \\
\hline
\end{tabular}

${ }^{\circ}$ Values are taken from Ref. 14. "Values are in kcal mol ${ }^{-1}$ at $633 \mathrm{~K}$. 
Table 4. The relevant bond lengths (in $A$ ) in TS structures optimized at B3LYP/6-31+ G(d,p) level

\begin{tabular}{ccccc}
\hline $\mathrm{R}$ & $\mathrm{Z}$ & $\mathrm{d}\left(\mathrm{C}^{5}-\mathrm{H}^{5}\right)$ & $\mathrm{d}\left(\mathrm{O}^{1}-\mathrm{H}^{5}\right)$ & $\mathrm{d}\left(\mathrm{O}^{2}-\mathrm{C}^{+}\right)$ \\
\hline & $\left(\mathrm{CH}_{3}\right)_{2} \mathrm{C}$ & 1.306 & 1.326 & 2.025 \\
& $\mathrm{H}_{3} \mathrm{C}$ & 1.302 & 1.326 & 2.011 \\
$\mathrm{CH}_{3}$ & $\mathrm{H}$ & 1.329 & 1.288 & 1.980 \\
& $\mathrm{Cl}$ & 1.386 & 1.215 & 1.906 \\
& $\mathrm{~N} \equiv \mathrm{C}$ & 1.502 & 1.130 & 1.748 \\
\hline $\mathrm{H}$ & & 1.325 & 1.297 & 1.999 \\
$\left(\mathrm{CH}_{3}\right)_{3} \mathrm{C}$ & $\mathrm{H}$ & 1.328 & 1.293 & 2.001 \\
$\mathrm{C}_{6} \mathrm{H}_{5}$ & & 1.335 & 1.291 & 2.023 \\
\hline
\end{tabular}

Taft s $\sigma^{*}$ values) were increased. For example, $\mathrm{d}\left(\mathrm{O}^{1} \cdot \mathrm{H}^{6}\right)$ and $\mathrm{d}\left(\mathrm{O}^{3}-\mathrm{C}^{4}\right)$ with $\mathrm{Z}=\mathrm{CN}$ were much shorter by $0.196 \AA$ and $0.277 \AA$, respectively, than those with $Z=\left(\mathrm{CH}_{3}\right)_{3} \mathrm{C}$. This indicates that the TS structure becomes tighter as the $Z$ substituent becomes a stronger electron-acceptor.

On the other hand, effects of the R-substituents on the TS structures were smaller than those of the $Z$-substituents. For example, $\mathrm{d}\left(\mathrm{O}^{1}-\mathrm{H}^{6}\right)$ bond length change between $\mathrm{Z}=\mathrm{H}$ and $\mathrm{Z}$ $=\left(\mathrm{CH}_{3}\right)_{3} \mathrm{C}$ was $0.038 \mathrm{~A}$, but $\mathrm{d}\left(\mathrm{O}^{1}-\mathrm{H}^{6}\right)$ bond length between $\mathrm{R}=\mathrm{H}$ and $\mathrm{R}=\left(\mathrm{CH}_{3}\right)_{3} \mathrm{C}$ was only $0.004 \mathrm{~A}$. Such a small change in the bond lengths with $R$-substituents was caused by the concurrent electronic and steric effects as discussed above.

Acknowledgements. This work was supported by INHA UNIVERSITY Research Grant

\section{References}

1. (a) Chuchani. G: Marquez. E.: Herize. A.: Dominguez. R. M.: Tosta. M.: Brusco, D. J. Phns. Org. (7hem. 2003. 16. 839. (b) Chuchani. G: Nunnez, O: Donninguez. R. M.: Rotinov, A.: Herize. A. J. Pths. Org. Chem. 2001, 16, 40. (c) Herize. A. Dominguez. R. M.: Rotinov. A.: Nunnez. $\mathrm{O}$ : Chuchani. G. $J$. Phws. Org. Chem. 1999. I2. 201. (d) Daly. N. J.: Ziolkowsky. F. J. Chem. Soc, Chem Conmun 1972.911. (e) Daly. N. J.: Ziolkowsky, F. Atust. J. Chem. 1971 24. 2451

2. Kim, C. K.: Kim. D. I.: Lee. H. W: Lee, B.-S; Kim, C. K. J. Comp. Chem. 2007. 28.625

3. (a) Taylor. R. In the Chemisty of Futctional Groups. Sipplementar Wohto B. Acid Derivaties: Patai. S.. Ed.: Wiley: London. 1979: Chap 15. (b) Halbrook. K. A. In The Chemisty of Acid Derivatives. Tapor and Gas-phase Reactions of Carboxylic Acids and Their Derivatives: Patai. S., Ed.: Wiley: Chichester. 1992: Chapt. 12. volume 2. (c) Snith. G. G.: Voorkess. K. 1; Kelly. F. M.
J. Chem. Soc. Chem. Commm. 1971. 789. (d) Gordon. A. S. Norris. W. P. J. Phos. Chem. 1965. 69. 3013. (e) Kwart. H.: Slutsky. T. J. Chent Soc. Chem. Conmm. 1972. 552. (I) Daly. N. $\mathrm{J}$ : Ziolkowshi, F. Atust. J. Chem. 1972, 25. 1453 .

4. Chuchani, G: Mishima, M.: Notario, R: Abboud, J. L. In Advances in Unantative Snucture-Property Relationship. Strtural Effect on Gas Phase Reactivities: Charton. M.: Charton. B.. Eds: JAl Press: Stannford. 1999: Vol. 2. p 83 and reterences cited therein.

5. Hancock. C. K.: Meyers. E. A.: Yager. B. T. J. An. Chent. Soc. $1961.83,4211$

6. Chuchani, G.: Nunnez, O.: Marcano, N.: Napolitano. S.; Rodriguez, H.: Dominguez, M.: Ascanio. J:- Rotinov, A.; Dominguez. R. M.: Herize. A. J. Phws Org Chent 2001. J I. 146.

7. Tatt. R. W. Steric Effects in Organic Chemismy. Newman. M. Ed.: Wiley: New York. 1956: Chapter 13.

8. Luiggi. M: Dominguez, R. M.: Rotinov. A.: Herize A.: Cordova. M.; Chuchani, G. int J. Chem. Kinetics 2001. 33,67.

9. Brusco, Y.: Dominguez, R. M: Rotinov, A; Herize. A; Cordova. M.: Chuchani. G. J. Phss. Org. Chem. 2002. 15.796.

10. (a) Xue. Y.: Lee. K. A.: Kim. C. K. Bull. Korew Chem. Soc. 2003. 24. 853, (b) Lee. 1.: Li. H. G.: Kim. C. K.: Lee. B.-S.: Kiml. C. K.: Lee. H. W. Bull. Korean Chem. Soc, 2003, 24. 583. (c) Kim, C. K: S. H. Yoon: J. Won: Kim, C. K. Bull. Koman Chem. Soc. 2006. 27, 1219.

11. Schlegel. H. B. In New Theoretical Concepts for Lnderstanding Organic Reactions: Bertran. I.: Csizmadia. I. G. Eds.: Kluwer: Dordrecht. 1989. pp 33-53.

12. Foresman, J. B.; Frisch, .E. Exploring Chenisty with Electronic Structure Hethod, 2nd Ed.: Gaussian Ine.: Pittsburgh. 1996; 09.

13. Frisch. M. J.: Trucks. G. W: Schlegel. H. B.: Scuseria, G. E. Robb. M. A.: Cheeseman. J. R.: Zahrzewski. V. G.: Montgomery. J. A.. Ir.: Stratmann. R. E.: Burant. J. C.: Dapprich. S.: Millam. J. M.: Daniels. A. D.: Kudin. K. N.: Strain. M. C.: Farkas. O.: Tomasi, J.: Barone. V.: Cossi, M.: Cammi, R.: Mennucei. B.: Pomelli, C.; Adamo. C.: Clitiord. S.; Ochterski. J:- Petersson. G. A.: Avala. P. Y. Cui, Q.: Morokuma, K.: Malick. D. K.: Rabuck. A. D.: Raghavachari. K.: Foresmant. J. B.: Cioslowski. T.: Ottiz. J. V.: Stetanov. B. B.: Liu. G.: Liashenko. A.: Piskolz. P.: Komaromi. 1.: Gomperts. R:: Martin. R. L:: Fox. D. I.: Keith. T.: Al-Laham. M. A.; Peng, C. Y.: Nanayakkara. A.: Gonzalez. C.: Challacombe. M.: Gill. P. M. W: Johnson. B.: Chen. W.: Wong. M. W: Andres. J. L.: Head-Gordon, M.; Replogle. E. S.; Pople. J. A. Gaussian 98 Revision A. 6: Gaussian. Inc: Pittsburgh. PA. 1998.

14. (a) Reed. A. E.: Curtiss. L. A: Weinhold. F. Chem. Rev 1988. 88 899. (b) Carpenter. J. E.: Weinhold. F. J. Mol Struct AHEOCHEth 1988. 169,41

15. Hansch. C.: Leo. A: Tatt, R. Chem Rev 1991. 91, 165.

16. (a) Han. I. S.: Kim. C. K.: Kim, C.-K.: Lee. H. W.; Lee. I. J. Phys. Chent A 2002. 106. 2554. (b) Kim. C. K.: Han. I. S.: Ryu. W. S.: Lee. H. W.: Lee. B.-S.: Kim. C. K. J. Pho Chent A 2006.110. 2500.

17. Glendening, E. D; Badenhoop, J. K; Reed, A. E; Capenter, J. E. Bohmann. J. A.: Morales. C. M.: Weinhold, F. NBO 5.0: Theoretical Chemistry Institute. University of Wisconsin: Madison. 2001. 